\title{
NEUROTROPISM OF HUMAN CORONAVIRUS 229E
}

\author{
Pierre J. Talbot, Sophie Ékandé, Neil R. Cashman*, \\ Samir Mounir and Janet N. Stewart \\ Centre de Recherche en Virologie \\ Institut Armand-Frappier, Université du Québec \\ Laval, Québec, Canada H7N 4Z3 \\ and \\ ${ }^{*}$ Montreal Neurological Institute \\ McGill University \\ Montreal, Québec, Canada H3A 2B4
}

\begin{abstract}
The 299E prototype strain of human coronavirus (HCV-229E) has so far been mainly associated with infections of the respiratory tract. In the present study, we show evidence for infection of the central nervous system (CNS) by HCV-229E, both in vitro and in vivo.

Various human cell lines of CNS origin were tested for their susceptibility to infection by HCV-229E. Production of viral antigens was monitored by indirect immunofluorescence with monoclonal antibodies and infectious progeny virions by plaque assay on the L132 human embryonic lung cell line. The SK-N-SH neuroblastoma and $\mathrm{H} 4$ neuroglioma cell lines were highly susceptible to infection. The U-87 MG and U-373 MG astrocytoma cell lines were also infectable by HCV-229E. We could also demonstrate infection of the MO3.13 cell line, which was established by fusion of human oligodendrocytes with a thioguanineresistant mutant of the TE671 (RD) human rhabdomyosarcoma cell line. An apparently more extensive infection of the MO3.13 cells, when compared to the parental cells, supports the notion that human oligodendrocytes are differentially susceptible to infection by this virus.
\end{abstract}

We also tested for HCV-229E gene expression in pathological brain specimens. For that purpose, we developed a reverse transcription-polymerase chain reaction (RT-PCR) assay to amplify a portion of the mRNA encoding the viral nucleocapsid protein. Using stringent laboratory conditions, viral RNA was detectable in brain tissue of 4 of 11 multiple sclerosis patients and none of 6 neurological and 5 normal controls.

These results strongly suggest neurotropism on the part of HCV-229E and emphasize the importance of further studies on the possible involvement of human coronaviruses in neurological diseases such as multiple sclerosis. 


\section{INTRODUCTION}

Human coronaviruses (HCV) are recognized as respiratory pathogens that are responsible for 15 to $35 \%$ of common colds ${ }^{1}$. Two prototype strains, named $229 \mathrm{E}$ and OC43, represent the two known serotypes. Besides infections of the respiratory tract, other pathologies have sporadically been associated with human coronaviruses. A seroepidemiological study has linked them with some pneumoniae, perimyocardites, meningites and radiculites ${ }^{2}$. Also, their involvement in enteric infections was suggested from various reports of their presence in stool specimens of infants and children with severe diarrhea $3,4,5$.

Another disease association that remains to be confirmed is the possible involvement of HCVs in neurological disorders, specifically multiple sclerosis (MS). The original report of coronavirus-like particles in the brain of an MS patient ${ }^{6}$ was rapidly followed by the description of two coronaviruses isolated from two MS patients ${ }^{7}$. Despite the closer relationship of these isolates to murine coronaviruses ${ }^{8}$, it was recently shown that their replication could be detected in brain tissue of some MS patients ${ }^{9}$ and that they could cause a demyelinating disease in primates ${ }^{10}$. Moreover, antibodies to both serotypes of human coronaviruses were detected in the cerebrospinal fluids of MS patients, which could result from replication of HCVs within the central nervous system ${ }^{11}$. Finally, the neurotropism of some murine strains of coronavirus is well recognized and actually provides a very useful animal model of virus-induced demyelinating disorders, given the close analogy of the clinical manifestations of the disease in rodents to multiple sclerosis ${ }^{12}$. Together, these indications constitute enough stimulus for renewed interest in the study of the neurotropism of human coronaviruses and their possible involvement in multiple sclerosis.

Very few studies have attempted to verify the replication of human coronaviruses in neural and glial cells of the nervous system. Pearson and Mims ${ }^{13}$ reported a productive infection of murine neurons in primary cultures by HCV-OC43, as well as the presence of viral antigen in astrocytes. However, infection of myelin-producing oligodendrocytes was not detected. In the same report, the authors also reported that human embryo brain cells, including astrocytes were susceptible to HCV-OC43 infection but did not produce infectious virus ${ }^{13}$. Collins and Sorensen ${ }^{14}$ showed that the U87-MG human glioblastoma cell line could be persistently infected with HCV-OC43. No studies have been reported so far on the neurotropism of $\mathrm{HCV}-229 \mathrm{E}$, a virus isolated from the human respiratory tract in $1966^{15}$.

In the present study, we report on the replication of HCV-229E in neural and glial cell lines and the presence of its genome in parts of the brains of some MS patients.

\section{MATERIALS AND METHODS}

\section{Virus and Cell Lines}

The 229E strain of HCV was originally obtained from the American Type Culture Collection (ATCC; Rockville, MD), plaque-purified twice and grown on the human embryonic lung cell line L132, as described previously 16,17. The following human neural and glial cell lines were obtained from the ATCC: H4 (neuroglioma, brain), SK-N-SH (neuroblastoma, metastasis to bone marrow), U-373 MG and U-87 MG (glioblastoma, astrocytoma). The MO3.13 human-human hybrid cell line was derived by lectin-enhanced polyethylene glycol-mediated somatic cell fusion between the thioguanine-resistant rhabdomyosarcoma mutant RD-TG.6, derived from the TE671 (RD) cell line (ATCC), and primary human oligodendrocytes obtained from cultures of human adult temporal lobectomies ${ }^{18}$. Similar to oligodendrocytes but unlike the parent tumor rhabdomyosarcoma line, MO3.13 cells have been demonstrated to express myelin basic protein and proteolipid protein by immunohistochemistry, Western immunoblotting and Northern blotting, and show surface immunoreactivity for galactocerebroside and myelin-associated glycoprotein. 
These cell lines were grown as monolayers at $37^{\circ} \mathrm{C}$, in a humidified atmosphere containing $5 \%(\mathrm{v} / \mathrm{v}) \mathrm{CO}_{2}$, using Dulbecco's modified Eagle's medium containing high glucose, Lglutamine and sodium pyruvate, and supplemented with $10 \%(\mathrm{v} / \mathrm{v})$ heat-inactivated fetal calf serum, without antibiotics (Gibco BRL Life Technologies, Inc., Burlington, Ontario, Canada). Cells were passaged every four days at a concentration of 100,000 cells per ml.

\section{Immunofluorescence Assay}

For immunofluorescence, approximately $1.5 \times 10^{6}$ cells (obtained by trypsinization of cell monolayers grown on plastic $25-\mathrm{cm}^{2}$ flasks, followed by pelleting) were mixed with an equal volume of HCV-229E virus stock diluted to give an MOI of 1 . Twenty-five microliters of this suspension was deposited into each well of a 12-well glass slide (Flow, ICN Biomedical Canada Ltd., Mississauga, Ontario, Canada) and infection allowed to continue for 20 or $40 \mathrm{~h}$ at $33^{\circ} \mathrm{C}$ (the optimal HCV-229E growth temperature ${ }^{17}$ ) and $5 \%$ $(\mathrm{v} / \mathrm{v}) \mathrm{CO}_{2}$. Slides were washed twice in Dulbecco's phosphate buffered saline (PBS) and fixed with cold acetone at $-20^{\circ} \mathrm{C}$ for $20 \mathrm{~min}$. Viral antigen was detected by adding a $1 / 10$ dilution of ascites fluids containing HCV-229E-specific monoclonal antibodies, designated 3-10H.5 or 4-9H.5 (ELISA titers: $1 / 144,000$ and $1 / 20,000$, respectively), or control ascites fluids prepared with the parental myeloma cells. After incubation at room temperature in a humidified chamber for $2 \mathrm{~h}$, the slides were washed twice with PBS and a $1 / 100$ dilution of fluorescein isothiocyanate-conjugated $F\left(a^{\prime}\right)_{2}$ goat antibodies to mouse immunoglobulins (Cappel, Organon Tecknika Inc., Scarborough, Ontario, Canada) were added for another $30 \mathrm{~min}$. Fluorescence was observed with a Leitz fluorescence microscope after mounting the slides with glass coverslips, using glycerol:PBS (9:1).

\section{Preparation of RNA and Reverse-Transcription Polymerase Chain Reaction}

Brain tissues were collected from a total of 11 patients diagnosed with multiple sclerosis and 11 control patients, five with normal autopsy reports and six with indications of other neurological diseases (Montreal Brain Bank, Montreal, Quebec and University Hospital, London, Ontario). Total RNA was extracted from coded central nervous system (CNS) tissues by the method of Chomczynski and Sacchi19. Briefly, 50 to $300 \mathrm{mg}$ of tissue were thawed and homogenized in $0.5 \mathrm{ml}$ of $4 \mathrm{M}$ guanidinium thiocyanate, extracted with phenol and chloroform and precipitated twice with ethanol. After washing with $70 \%$ $(\mathrm{v} / \mathrm{v})$ ethanol, the pellets were air-dried and resuspended in water. The extracted RNA was first tested for the presence of human myelin basic protein or actin mRNAs by reversetranscription - polymerase chain reaction (RT-PCR) to insure that it was undegraded 20 .

For RT-PCR, HCV-229E primers were designed to amplify either of two regions of about 300 bases in the gene coding for the nucleocapsid protein of this virus, at positions 498 to 806 or 964 to $1265^{21}$. To confirm the identity of the amplified products, hybridization was performed with oligonucleotide probes derived from sequences located between each pair of primers (bases 693-716 and 1080-1103, respectively ${ }^{21}$ ). Approximately $1 \mu \mathrm{g}$ of RNA was reverse transcribed at $37^{\circ} \mathrm{C}$ for $35 \mathrm{~min}$ with $20 \mathrm{U}$ of Moloney murine leukemia virus reverse transcriptase (Pharmacia Canada Inc., Baie d'Urfé, Québec, Canada) and 50 pmol of both up- and downstream primers (to target both positiveand negative-stranded RNA) in $10 \mathrm{mM}$ Tris- $\mathrm{HCl}(\mathrm{pH} \mathrm{8.8),} 50 \mathrm{mM} \mathrm{KCl}, 0.1 \%$ (v/v) Triton X-100 (1X Taq polymerase buffer; BIO/CAN, Mississauga, Ontario, Canada), 1.0 mM (each) dATP, dCTP, dGTP and dTTP (Pharmacia), $40 \mathrm{U}$ of RNAguard (Pharmacia) and $4.0 \mathrm{mM} \mathrm{MgCl}$. Twenty microliters of the reverse transcription was added to $80 \mu \mathrm{l}$ of a PCR mix overlaid with mineral oil. This mixture contained $1 \mathrm{X}$ Taq polymerase buffer (BIO/CAN), $2.5 \mathrm{U}$ of $\mathrm{Taq}$ polymerase (BIO/CAN), $50 \mathrm{pmol}$ of both up- and downstream primers, $0.25 \mathrm{mM}$ (each) dATP, dCTP, dGTP and dTTP (Pharmacia) and $2.4 \mathrm{mM}$ $\mathrm{MgCl}_{2}$. PCR was performed using a modification of the original method 22 . An amplification cycle of $1 \mathrm{~min}$ at $94^{\circ} \mathrm{C}, 2 \mathrm{~min}$ at $60^{\circ} \mathrm{C}$ and $2 \mathrm{~min}$ at $72^{\circ} \mathrm{C}$ was repeated 30 times and was followed by an extension period of $7 \mathrm{~min}$ at $72^{\circ} \mathrm{C}$. Twenty $\mu$ l of reaction products were loaded onto $1.5 \%(\mathrm{wt} / \mathrm{vol})$ agarose gels, allowed to migrate and transferred to nitrocellulose filters according to the method of Southern ${ }^{23}$. Blots were hybridized with 
32P-end-labeled oligonucleotide probes at $50^{\circ} \mathrm{C}$ for $16 \mathrm{~h}$ in a buffer containing $6 \mathrm{x} \mathrm{SSC}, 1 \mathrm{x}$ Denhardt's solution, $0.05 \%$ (wt/vol) pyrophosphate and $100 \mu \mathrm{g} / \mathrm{mL}$ sonicated salmon sperm DNA. The blots were washed $3 \times 15 \mathrm{~min}$ at room temperature and for $20 \mathrm{~min}$ at $60^{\circ} \mathrm{C}$ in $6 \mathrm{x} \mathrm{SSC}, 0.05 \%$ (wt/vol) pyrophosphate and exposed to X-ray film (Kodak, Rochester, NY) at $-70^{\circ} \mathrm{C}$ for 48 or $96 \mathrm{~h}$.

The detectability level of the RT-PCR assay was evaluated by cloning the amplification product of RNA prepared from HCV-229E-infected L132 cells into the SmaI site of the pGEM $3 Z$ vector (Promega, Fisher, Montréal, Québec, Canada). Five $\mu \mathrm{g}$ of HindIII-linearized plasmid were transcribed in vitro in the presence of $20 \mathrm{mM}$ Tris-HCl ( $\mathrm{pH}$ 8.0), $4 \mathrm{mM} \mathrm{MgCl} 2,1 \mathrm{mM}$ spermidine, $25 \mathrm{mM} \mathrm{NaCl}$ (transcription buffer; Stratagene, La Jolla, California), $0.4 \mathrm{mM}$ (each) ATP, GTP and UTP, 20 U T7 DNA polymerase and $2 \mathrm{U}$ RNase Block II (Stratagene) and $3 \mu \mathrm{M}[\alpha-32 \mathrm{P}] \mathrm{CTP}$. The amount of transcript was evaluated by ${ }^{32} \mathrm{P}$ incorporation and the number of molecules detectable was estimated by performing RT-PCR on ten-fold serial dilutions of the transcript.

\section{RESULTS AND DISCUSSION}

\section{Infectability of neural and glial cell lines}

We found that all neural and glial cell lines tested could be infected with HCV-229E, as revealed by immunofluorescence with virus-specific monoclonal antibodies (MAbs). Representative results are shown in Fig. 1.
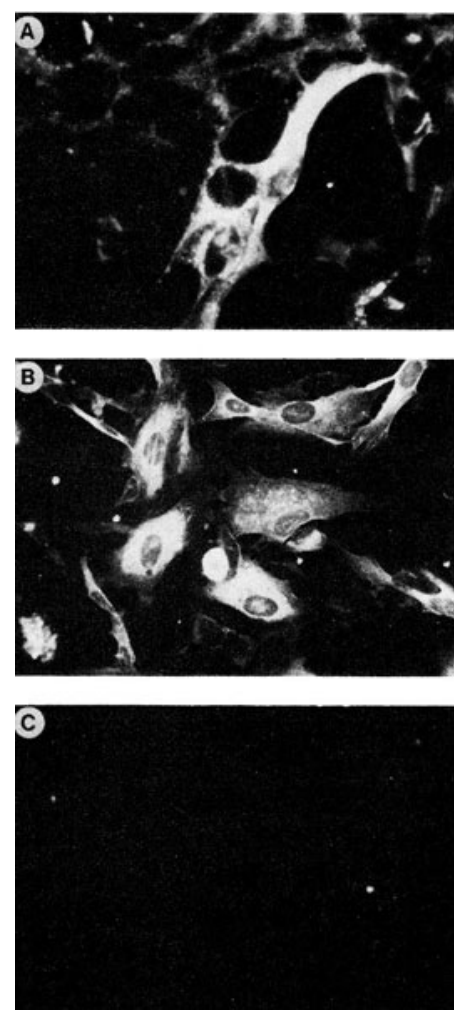

Figure 1. Immunodetection of HCV-229E antigens in neural and glial cell lines. Panel A: MO3.13 cells at $40 \mathrm{~h}$ post-infection, revealed with the 3-10H.5 MAb. Panel B: SK-N-SH cells at $20 \mathrm{~h}$ postinfection, revealed with the 4-9H.5 MAb. Panel C: SK-N-SH cells at $20 \mathrm{~h}$ post-infection, revealed with control antibody (magnification $=100 \mathrm{X}$ ). 
Varying degrees of antigen expression were observed in the different human neural and glial cells lines, as summarized in Table 1.

It is noteworthy that cells related to neurons, astrocytes and oligodendrocytes were susceptible to infection by the human coronavirus $229 \mathrm{E}$, since the same situation is observed in the mouse with the neurotropic strains of murine hepatitis virus ${ }^{24}$. Indeed, this is the first report on the infection of such cells by HCV-229E. Interestingly, it appears that immortalized human oligodendrocytes were infected with this virus. The more extensive infection observed in these cells when compared to the parental rhabdomyosarcoma cell line, at least at $40 \mathrm{~h}$ post-infection (Table 1), suggests that the oligodendrocyte phenotype

Table 1. Percentage of infected cells after infection with an MOI of 1 for 20 or $40 \mathrm{~h}$.

\begin{tabular}{|c|c|c|c|}
\hline \multicolumn{2}{|c|}{ Cells } & \multicolumn{2}{|c|}{$\begin{array}{l}\text { Percent infected cells } \\
\text { at each time post-infection } \\
(\%)\end{array}$} \\
\hline Line designation & Type & $20 \mathrm{~h}$ & $40 \mathrm{~h}$ \\
\hline $\begin{array}{c}\text { SK-N-SH } \\
\mathrm{H} 4\end{array}$ & $\underset{"}{\text { Neural }}$ & $\begin{array}{l}90 \\
18\end{array}$ & $\begin{array}{l}90 \\
20\end{array}$ \\
\hline $\begin{array}{l}\mathrm{U}-373 \mathrm{MG} \\
\mathrm{U}-87 \mathrm{MG}\end{array}$ & Astrocyte & $\begin{array}{l}3 \\
2\end{array}$ & $\begin{array}{l}60 \\
60\end{array}$ \\
\hline $\begin{array}{c}\text { MO3.13 } \\
\text { TE671 (RD) }\end{array}$ & $\begin{array}{l}\text { Oligodendrocyte } \\
\text { MO3.13 parental }\end{array}$ & $\begin{array}{c}6-10 \\
6\end{array}$ & $\begin{array}{c}20 \\
3\end{array}$ \\
\hline L132 & Lung & $70-80$ & 80 \\
\hline
\end{tabular}

was involved in susceptibility. Even though final proof on the susceptibility of human oligodendrocytes to coronavirus infection will require the use of primary oligodendrocyte cultures and immunohistochemistry on human CNS tissue sections, the infection of these myelin protein-producing cells is indeed relevant to the possibility of the induction of demyelinating disease in humans by coronaviruses.

\section{Detection of viral RNA in brain samples}

Having demonstrated infection of human and glial cells in vitro by HCV-229E, we wanted to test for the presence of this virus in CNS tissue of multiple sclerosis patients. A previous study had used classical hybridization to search for the RNA of HCV-OC43 in four MS brain autopsy samples, with negative results 25 . Thus, we wanted to develop a more sensitive assay, capable of detecting very low amounts of viral nucleic acid, characteristic of persistent infections. For that purpose, we developed a polymerase chain reaction (PCR) assay, modified to include a reverse transcription step from extracted RNA (RT-PCR). As shown in Fig. 2, the detectability level of our assay was less than 60,000 molecules. Moreover, this number is most likely an overestimation since the in vitro transcription may have produced a proportion of incomplete transcripts which could not be amplified by RT-PCR. Similar detectability levels of RT-PCR were reported in other systems ${ }^{26}$. Since the target sequence is located on the most abundant viral mRNA as well as on the genome, and since we designed the assay to amplify both positive- and negativesense RNAs, we estimate that a single infected cell should be detectable in our procedure.

We applied our HCV-229 RT-PCR assay to RNA extracted from frozen brain autopsy samples from both MS and control patients. Positive signals were obtained from four of eleven MS patients and none of eleven controls, which included five histopathologically normal patients, and six patients whose autopsy report indicated Alzheimer's disease (four patients), subacute meningoencephalitis (one patient) and ischemic vascular disease (one patient). Representative results are shown in Fig.3. 


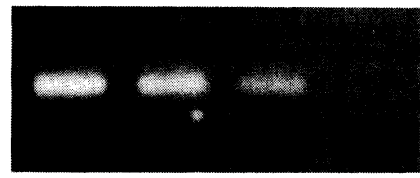

$6 x$

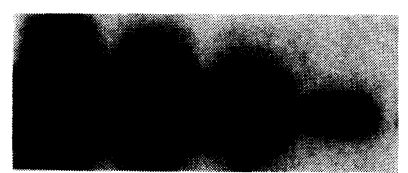

$\begin{array}{llll}10^{8} & 10^{7} & 10^{6} & 10^{4}\end{array}$

$\mathrm{EtBr}$

$32 p$

Figure 2. Determination of the detectability of the HCV-229E RT-PCR. The estimated amounts of transcripts indicated on the figure were amplified by RT-PCR and analyzed on agarose gels, which were stained with ethidium bromide $(\mathrm{E} t \mathrm{Br})$, followed by Southern hybridization with an internal radiolabeled oligonucleotide probe $\left({ }^{32} \mathrm{P}\right)$.

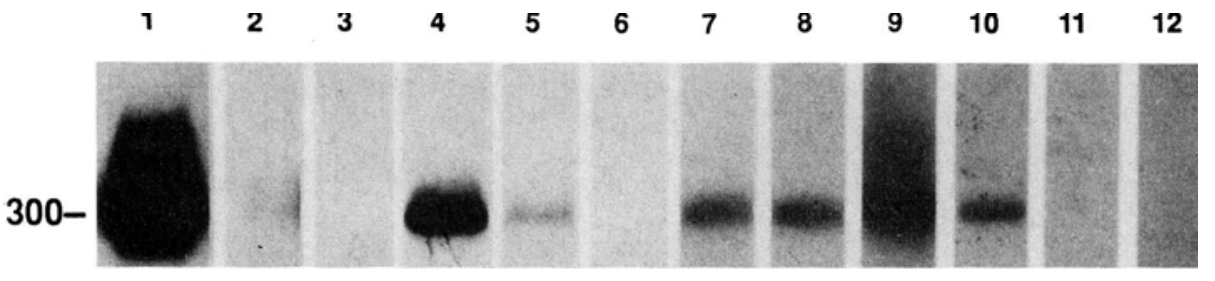

Figure 3. Detection of HCV-229E in brain samples by RT-PCR. The templates in each lane are RNA extracted from: lane 1, L132 cells infected with HCV-229E; lane 2, mock-infected L132 cells; lane 3, no RNA; lane 4, mouse brain mixed with 170 pg RNA extracted from HCV-229Einfected L132 cells; lane 5, mouse brain mixed with 1.7 pg RNA extracted from HCV-229Einfected L132 cells; lane 6, mouse brain; lanes 7-12, specimens from MS patients (positive samples were from: lanes 7 and 9 , white matter; lane 8 , gray matter; lane 10 , plaque tissue). Blots were exposed to X-ray film for 48 (lanes 1-6) or $96 \mathrm{~h}$ (lanes 7-12). The migration position of the $300 \mathrm{bp} \mathrm{HCV}-229 \mathrm{E}$ amplified product is indicated on the left. 
The results of our study indicate for the first time that the 229E strain of human coronavirus, which has so far only been associated formally with respiratory infections, has the capacity to infect cells of the central nervous system, as monitored by in vitro infection of transformed cell lines. Moreover, its genome is expressed in some human brains. Interestingly, it was shown in the animal model of coronavirus-induced demyelinating disease that neurotropic coronaviruses can gain access to the central nervous system from the respiratory tract, through the olfactory and trigeminal nerves 27 . Thus, it is conceivable that the same type of spread from the upper respiratory tract to the CNS could occur in humans and be relevant to the development of a neurologic disease in genetically predisposed individuals 28,29 .

An association of HCV-229E with multiple sclerosis cannot be inferred from our pilot RT-PCR study, given the small number of clinical samples analyzed. Moreover, the establishment of an etiologic link with the disease will require large scale studies involving an epidemiological component. Nevertheless, we believe that research efforts are needed to establish the pathological relevance of the HCV-229E neurotropism suggested by our study. Interestingly, we recently found evidence for the sharing of amino acid sequences between HCV-229E and myelin basic protein ${ }^{16}$. Since this protein appears to be a target for the immune system of MS patients ${ }^{30}$, the possibility that molecular mimicry of myelin antigens by a virus, be it a coronavirus or another virus sharing similar mimetic properties, could be involved in the establishment of this degenerative autoimmune neurologic disease also warrants attention.

\section{ACKNOWLEDGMENTS}

This work was supported by grant MT-9203 from the Medical Research Council of Canada to P.J.T., who also gratefully acknowledges salary support in the form of a University Research Scholarship from the National Sciences and Engineering Research Council of Canada (NSERC). Funding for the developement of oligodendrocyte cell lines was provided by the Network for Neural Regeneration and Recovery, one of fifteen Networks of Centres of Excellence supported by the Government of Canada. J.N.S. is grateful to the Institut Armand-Frappier for studentship support. We thank Francine Lambert for excellent technical assistance. We are grateful to Dr. Jack P. Antel (Montreal Neurological Hospital) for his help in setting-up the RT-PCR study, to George P.A. Rice, Vince L. Morris and George Ebers (University of Western Ontario, London, Ontario), and to Karen Hellauer (The Montreal Brain Bank) for providing frozen CNS tissue. We also thank Dr. Gordon S. Francis (Montreal Neurological Hospital) for help in selecting some samples and Dr. Mark S. Freedman (Montreal Neurological Institute) for helpful advice.

\section{REFERENCES}

1. K. McIntosh, In: "Virology, 2nd edn.”, B.N. Fields, D.M. Knipe et al., eds., p. 857, Raven Press, New York (1990).

2. N. Riski, and T. Hovi. J. Med. Virol. 6: 259 (1980).

3. S. Resta, J.P. Luby, C.R. Rosenfeld, and J.D. Siegel. Science 229: 978 (1985).

4. M. Battaglia, N. Passarini, A. DiMatteo, and G. Gerna. J. Inf. Dis. 155: 140 (1987).

5. M.L. Mortensen, C.G. Ray, C.M. Payne, A.D. Friedman, L.L. Minnich, and C. Rousseau. Amer. J. Dis. Child. 139: 928 (1985).

6. R. Tanaka, Y. Iwasaki, and H.J. Koprowski. J. Neurol. Sci. 28: 121 (1976).

7. J.S. Burks, B.L. DeVald, L.D. Jankovsky, and J.C. Gerdes. Science 209: 933 (1980).

8. S. Weiss. Virology 126: 669 (1983).

9. R.S. Murray, B. Brown, D. Brian, and G.F. Cabirac. Ann. Neurol. 31: 525 (1992).

10. R.S. Murray, G.-Y. Cai, K. Hoel, J.Y. Zhang, K.F. Soike, and G.F. Cabirac. Virology 188: 274 (1992).

11. A. Salmi, B. Ziola, T. Hovi, and M. Reunanen. Neurology 32: 292 (1982). 
12. V. ter Meulen, P.T. Massa, and R. Dörries. In: "Handbook of Clinical Neurology: Viral Disease, Revised Series", P.J. Vinken, G.W. Bruyn, and H.L. Klawans, eds., Vol. 12 (56), p. 439, Elsevier, New York (1989).

13. J. Pearson, and C.A. Mims. J. Virol. 53: 1016 (1985).

14. A.R. Collins, and O. Sorensen. Microbial Path. 1: 573 (1986).

15. D. Hamre, and J.J. Procknow. Proc. Soc. Exp. Biol. Med. 121: 190 (1966).

16. P. Jouvenne, S. Mounir, J.N. Stewart, C.D. Richardson, and P.J. Talbot. Virus Res. 22: 125 (1992).

17. N. Arpin, and P.J. Talbot. In: "Coronaviruses and Their Diseases", D. Cavanagh and T.D.K. Brown, eds., p. 73, Plenum Press, New York (1990).

18. G. Trudel, J. Antel, and N.R. Cashman. Soc. Neurosci. Abst. 17: 31(1991).

19. P. Chomczynski, and N. Sacchi. Anal. Biochem. 162: 156 (1987).

20. J.N. Stewart, S. Mounir, and P.J. Talbot. In: "Diagnosis of Human Viruses by the Polymerase Chain Reaction, Frontiers in Virology, Vol. 1", Y. Becker and G. Darai, eds., p. 316, Springer Verlag, Berlin (1992).

21. S.S. Schreiber, T. Kamahora, and M.M.C. Lai. Virology 169: 142 (1989).

22. R.K. Saiki, D.H. Gelfand, S. Stoffel, S.J. Scharf, R. Higuchi, G.T. Horn, K.B. Mullis, and H.A. Erlich. Science 239: 487 (1988).

23. E. Southern. Methods Enzymol. 68: 152 (1979).

24. H. Wege, S. Siddell, and V. ter Meulen. Curr. Top. Microbiol. Immunol. 99: 165 (1982).

25. O. Sorensen, A. Collins, W. Flintoff, G. Ebers, and S. Dales. Neurology 36: 1604 (1986).

26. R.E. Gama, P.J. Hughes, C.B. Bruce, and G. Stanway. Nucl. Acids Res. 16: 9346 (1988).

27. S. Perlman, G. Jacobsen, A.L. Olson, and A. Afifi. Virology 175: 418 (1990).

28. T.H. Maugh II. Science 195: 768 (1977).

29. P. Talbot, and P. Jouvenne. Médecinel Sciences 8: 119 (1992).

30. K. Ota, M. Matsui, E.L. Milford, Mackin, G.A., H.L. Weiner, and D.A. Hafler. Nature 346: 183 (1990). 